\title{
Paraguay: Report on the Observance of Standards and Codes- FATF Recommendations for Anti-Money Laundering and Combating the Financing of Terrorism
}

This Report on the Observance of Standards and Codes on the FATF Recommendations for AntiMoney Laundering and Combating the Financing of Terrorism for Paraguay was prepared by a staff team from the International Monetary Fund, using the assessment methodology adopted by the FATF in February 2004 and endorsed by the Executive Board of the IMF in March 2004. The views expressed in this document, as well as in the full assessment report, are those of the staff team and do not necessarily reflect the views of the government of Paraguay or the Executive Board of the IMF.

The policy of publication of staff reports and other documents by the IMF allows for the deletion of market-sensitive information.

\author{
Copies of this report are available to the public from \\ International Monetary Fund • Publication Services \\ 700 19th Street, N.W. • Washington, D.C. 20431 \\ Telephone: (202) 6237430 • Telefax: (202) 6237201 \\ E-mail: publications@imf.org • Internet: http://www.imf.org
}

\section{International Monetary Fund Washington, D.C.}





\section{INTERNATIONAL MONETARY FUND}

\section{PARAGUAY}

Report on Observance of Standards and Codes (ROSC) - FATF Recommendations for Anti-Money Laundering and Combating the Financing of Terrorism (AML/CFT)

Prepared by the Legal Department

Approved by Sean Hagan

December 2008 


\section{ACCRONYMS}

$\begin{array}{ll}\text { AML/CFT } & \text { Anti-Money Laundering and Combating the Financing of Terrorism } \\ \text { CDD } & \text { Customer due diligence } \\ \text { CNV } & \text { National Securities Commission } \\ \text { DNFBP } & \text { Designated Non-Financial Businesses and Professions } \\ \text { FATF } & \text { Financial Action Task Force } \\ \text { FI } & \text { Financial institution } \\ \text { FT } & \text { Financing of terrorism } \\ \text { INCOOP } & \text { Instituto Nacional de Cooperativismo (National Institute of Cooperatives) } \\ \text { LEG } & \text { Legal Department of the IMF } \\ \text { ML } & \text { Money laundering } \\ \text { MLA } & \text { Mutual legal assistance } \\ \text { NPO } & \text { Nonprofit organization } \\ \text { OAG } & \text { Office of the Attorney General } \\ \text { PEP } & \text { Politically exposed person } \\ \text { ROSC } & \text { Report on Observance of Standards and Codes } \\ \text { SENAD } & \text { Secretaría Nacional Antidrogas (National Antidrug Secretariat) } \\ \text { SEPRELAD } & \text { Secretaría de Prevención de Lavado de Dinero o Bienes (Money Laundering } \\ & \text { Prevention Secretariat) } \\ \text { SIB } & \text { Superintendency of Banks } \\ \text { SIS } & \text { Superintendency of Insurance } \\ \text { STR } & \text { Suspicious Transaction Report } \\ \text { UAF } & \text { Unidad de Análisis Financiero (Financial Analysis Unit) } \\ \text { UN } & \text { United Nations Organization } \\ \text { UNSCR } & \text { United Nations Security Council Resolution } \\ & \end{array}$




\section{A. Introduction}

1. This Report on the Observance of Standards and Codes for the FATF 40 Recommendations for Anti-Money Laundering (AML) and 9 Special Recommendations on Combating the Financing of Terrorism (CFT) was prepared by the Legal Department of the $\mathrm{IMF}^{1}$. The report provides a summary of the AML/CFT measures in place in Paraguay and of the level of compliance with the FATF 40+9 Recommendations, and contains recommendations on how the AML/CFT system could be strengthened. The assessment is based on the information available at the time of the mission from July 1st through 16, 2008 and was conducted using the 2004 Assessment Methodology. The detailed assessment report (DAR) on which this document is based was adopted by the Financial Action Task Force for South America (GAFISUD), on December 3, 2008. The views expressed here, as well as in the full assessment report, are those of the IMF assessment team and do not necessarily reflect the views of the Government of Paraguay or the Executive Board of the IMF.

\section{B. Key Findings}

2. The substantial dollar contraband trade that occurs on the borders shared with Argentina and Brazil facilitates money laundering in Paraguay. Paraguay is located at the center of an important regional transit zone flanked by Bolivia, Brazil and Argentina. Paraguay is considered to be a major transit point for narcotics trafficking, smuggling, and counterfeit goods destined for other countries in South America. Paraguay is also the leading marijuana-producing country in South America. These crimes, along with corruption of local officials, appear to be the main offences generating earnings that can potentially be laundered in the country. Ciudad del Este, on Paraguay's border with Brazil and Argentina, represents the heart of Paraguay's informal economy and is believed to facilitate much of the money laundering taking place in Paraguay.

\section{Under the leadership of a new Director of the Paraguay's financial intelligence unit} (Unidad de Análisis Financiero - UAF) appointed in August 2007, there has been notable progress in the quality and coverage of AML regulations. However, the country still falls short of complying with most of the FATF Recommendations and, where legal provisions exist, implementation is generally not effective. Furthermore, the level of awareness of money laundering and financing of terrorism (ML/FT) risks is low in both the public and private sectors.

\section{Achievements in the implementation of Paraguay's AML framework remain modest} since the criminalization of the ML offence in 1996. The ML offense does not extend to an adequate range of predicate offenses and FT is not yet criminalized. Although relevant statistics are not routinely kept or updated, the mission could confirm that at least 15 convictions for ML (with only six confirmed and final rulings) have been achieved since 1997. While the number of convictions obtained is respectable relative to other countries in the region, the number remains low considering the perceived level of criminal conduct. Corruption at all levels in the public sector is

\footnotetext{
${ }^{1}$ The assessment team consisted of: A. Antonio Hyman-Bouchereau (team leader), Francisco Figueroa, and Mariano Federici (all LEG); André Cuisset (consultant for LEG) and Carolina Claver (National Securities Commission of Argentina, Assessor on behalf of the Financial Action Task Force for South America GAFISUD); Esteban Fullin (observer, GAFISUD).
} 
currently a serious obstacle to combating ML and serious predicate offences, and poses a major threat to the country's development.

5. Paraguay has not been confronted with terrorism at the national level, as there are no local subversive organizations active in the country. Nevertheless, the presence of organized criminal groups operating at Paraguay's border with Brazil and Argentina has given rise to allegations that proceeds from the various forms of offences perpetrated in this area could possibly be diverted to finance terrorist activities in the Middle East. Although the authorities confirmed that significant amounts of money originating near Paraguay's border with Brazil and Argentina are regularly sent to the Middle East and elsewhere both through wire transfers and informal means, they could not confirm without reservations the incidence of FT in Paraguay. Although FT activity at Paraguay's border with Brazil and Argentina has not been clearly established, the combination of illicit activity in the area and weak law enforcement is a cause of concern and should be given priority attention by the authorities. There are no provisions that would allow the authorities to freeze suspected terrorist assets in accordance with the relevant UN Security Council Resolutions (UNSCRs).

\section{The Financial Analysis Unit (Unidad de Análisis Financiero - UAF) lacks an} adequate legal framework and a governance structure that provides operational independence. The UAF also lacks sufficient resources to effectively perform its mission.

7. The regime of preventive measures imposed on financial institutions is generally weak. The mission identified a number of deficiencies within the regime, notably in the areas of customer due diligence on beneficial owners, reporting of suspicious transactions, wire transfers, internal control systems, regulation and supervision by competent authorities, training, and resources.

\section{The level of implementation and compliance with respect to the FATF}

Recommendations is low in the financial sector. Key factors contributing to this low level of implementation and compliance included the lack of ongoing and effective supervision by competent authorities, particularly within the securities, insurance, and cooperatives sectors; the lack of supervisory resources available; and the lack of effective and dissuasive sanctions for noncompliance.

9. The deficiencies in the AML/CFT preventative measures applicable to financial institutions apply also to DNFBPs, since the core obligations for both DNFBPs and financial institutions are based on the same general AML/CFT regime. In addition, the AML Law does not cover certain types of non-financial businesses and professions.

\section{Legal Systems and Related Institutional Measures}

10. The money laundering offence under Article 196 of the Criminal Code (CC) is not in line with the UN Vienna Convention (arts. 3.1(b) \&(c)) and the Palermo Convention. In addition, under Paraguayan legislation, ML is a misdemeanor (as opposed to a crime), which only carries a sanction of imprisonment not exceeding five years in prison or a fine. The categorization of ML as a misdemeanor, together with limited resources and capacity across all relevant government agencies, is a major factor that prevents authorities from applying effective, proportional and dissuasive sanctions to ML offenders. The lack of clarity as to whether a prior conviction for the predicate offence is necessary when proving that property is the proceeds of crime represents an additional 
obstacle to the effective prosecution of ML offences. Moreover, the narrow range of predicate offences restricts the authorities' ability to prosecute ML and to grant legal assistance and extradition requests related to ML to other countries.

11. Although Paraguay is a Party to the UN International Convention for the Suppression of the Financing of Terrorism, its legislation does not include provisions that criminalize FT. Paraguay does not have specific provisions that would allow freezing terrorist funds or other assets of persons and legal entities designated pursuant to UNSCR 1267 or of persons and legal entities designated in the context of UNSCR 1373.

12. In recent times, the country has made significant efforts to strengthen the UAF. Paraguay's UAF was established in 1997 within the Money Laundering Prevention Secretariat (Secretaría de Prevención de Lavado de Dinero o Bienes - SEPRELAD) of the Ministry of Industry and Commerce, although it only became operational in 2004. The organizational structure of the SEPRELAD, which is comprised of high-level officials and chaired by the Minister of Industry and Commerce, hinders the efficacy of this body to carry out its main function of ensuring the implementation of Law 1015/97 (the AML Law). In practice, the UAF has assumed all of the functions and duties attributed by the AML Law to SEPRELAD, notwithstanding the inadequacy of its financial and human resources. Since the appointment of a new UAF Director in August 2007, significant efforts have been carried out to strengthen the UAF and overcome the legacy of weak and erratic leadership that has beleaguered it since it commenced operations. Since the appointment of the new director, UAF has adopted a policy of reinforcement of the operational capacity through the hiring and training of additional analysts, and the updating of the AML regulation.

\section{The budget allocated to the UAF is insufficient to allow it to be fully}

operational, particularly in the area of database processing, and to provide adequate salaries to its qualified employees. More than half of the analyses of suspicions transactions reports (STRs) which the UAF transmits to the Office of the Attorney General (OAG), do not lead to the commencement of a criminal investigation. Only a small number of the criminal convictions for ML to date have resulted from financial intelligence provided through the UAF. Paraguay should reexamine the law on the money laundering with regard to the SEPRELAD, and take measures to ensure the UAF is operationally autonomous and allocate the necessary resources to fulfill its mission.

14. Paraguay has not implemented comprehensive measures to detect the physical crossborder transportation of currency and bearer negotiable instruments that are related to ML or FT. The country's airports and land border crossings lack adequate controls for cross-border cash movements. Persons transporting U.S. $\$ 10,000$ into or out of Paraguay are required to file a customs report, but these reports are not collected or checked.

\section{Preventive Measures - Financial Institutions}

15. The AML regime in Paraguay provides the basic legal and regulatory framework for preventing money laundering from taking place within the financial sector. However, this framework needs further strengthening in a number of areas. SEPRELAD has taken a number of measures to strengthen the regime, for example, by issuing sector specific resolutions (rules issued by the SEPRELAD Council) with respect to customer identification and due diligence. However, these 
resolutions should be modified to adapt them to the activities of each sector, particularly in areas of politically exposed persons (PEPs), beneficial ownership, wire transfers, money remitters, internal control systems, internal audit function, designation of compliance officers, training, and other related obligations. For the purposes of the assessment, the resolutions issued by SEPRELAD are considered "other enforceable means", as they set out enforceable requirements with sanctions for noncompliance. However, there is no evidence supporting enforcement actions and/or sanctions imposed on financial institutions for non-compliance with these resolutions.

16. The AML Law does not cover the full range of financial institutions required by the FATF Recommendations. For instance, individuals and companies providing the following activities are not covered : financial leasing, the transfer of money or value, trading in transferable securities and commodity futures trading, safekeeping and administration of cash or liquid securities on behalf of other persons, insurance agents and brokers, securities brokers, and cooperatives other than credit and consumer cooperatives.

17. Given the perceived level of criminal activity, the number of STRs appears low, with the majority received from the banking and insurance sector. The low number of STRs is possibly related to inconsistencies in the interpretation of the SEPRELAD resolutions, coupled with the lack of effective supervision across the entire financial sector. SEPRELAD should provide additional guidance to financial institutions on how to detect a suspicious transaction.

18. All supervisory authorities lack sufficient resources to carry out their functions, including financial support, personnel, and technology. The lack of resources has negatively impacted the level of supervision in sectors like insurance, securities, cooperatives, the training of all supervisors and financial institutions, and the application of sanctions for noncompliance, given that some sectors are not being supervised for AML.

19. The authorities have addressed the existence of informal money or value transfer systems. Based on anecdotal evidence, it appears these informal systems are operating in Paraguay. The Paraguayan authorities should review the existence of informal remittance businesses for purposes of registration or licensing and AML/CFT oversight.

\section{E. Preventive Measures - Designated Non-Financial Businesses and Professions (DNFBPs)}

20. The list of non-financial businesses and professions covered under Article 13 of the AML Law falls short of the FATF standard. In particular, lawyers, notaries, other independent legal professionals and accountants are not covered. The provision of trust and company services is not covered either (this service is provided by lawyers). Lawyers are not required to submit STRs and are not subject to other AML/CFT measures.

21. There is limited indication that covered DNFBPs are in fact implementing the required preventive measures. No systems exist for monitoring and ensuring compliance of DNFBPs with AML/CFT requirements and little training has been provided to DNFBPs. No STRs have been submitted by DNFBPs. 


\section{F. Legal Persons and Arrangements \& Non-Profit Organizations}

22. Legal entities have legal status from the moment they are entered in the National Directorate of Public Registries. With respect to legal persons, the information available in the Public Registry generally relates to the incorporation of Paraguayan companies and the registration of foreign companies authorized to operate in Paraguay, including the composition of the board of directors. The changes of shareholders are not registered. Records are manual and only record information from 1986 onwards (i.e. from five years after the creation the National Directorate of Public Registries). The entries are not regularly updated. Companies with bearer shares may be incorporated but there is no appropriate provision to ensure transparency of the share ownership. Prior to the creation of the National Directorate of Public Registries, records were registered with the courts. While some of these records have been recovered from the courts, the vast majority of them have been reported lost. Moreover, there are no provisions ensuring adequate transparency concerning the beneficial ownership of legal persons. The mission was unable to obtain exact information on the number of registered corporations or non-profit organizations since it is still being maintained manually.

23. Trust documents are required to be registered only when transfer of ownership rights of property subject to registration, such as real estate and motor vehicles. Accordingly, trust documents involving any other type of property are not subject to any registration requirements. Besides, there are no provisions or mechanisms to ensure transparency concerning the identity ultimate beneficiary of the trust.

24. Paraguay has not reviewed the adequacy of domestic laws and regulations that relate to nonprofit organizations (NPOs). Available sources of information have not been used to evaluate the activities, size and other relevant features of this sector.

\section{G. National and International Co-operation}

25. Cooperation and coordination among law enforcement authorities is limited to a narrow range of areas, which significantly affects the effective detection and pursuit of serious offences, particularly those committed by organized crime, such as drug trafficking offences. There is no centralized responsibility for operational and policy coordination in the area of AML/CFT. However, the UAF has taken the initiative in organizing domestic coordination between the different supervisory and law enforcement. While the UAF maintains regular contact with the other agencies essentially regarding AML/CFT training and awareness-raising - the unsystematic approach to coordination results in only moderate cooperation between agencies and insufficient sharing of information.

26. With respect to international cooperation, although the $\mathrm{OAG}$ appears to have the means to expedite the mutual legal assistance (MLA), the effectiveness of these measures and mechanisms are difficult to assess due to the limited information available. There may be delays when dealing with requests that are not transmitted directly to the OAG but the lack of systematic compilation of data and statistics on all incoming and outgoing requests prevents the mission to form a comprehensive view on the use of mutual legal assistance. 
27. In any event, given the limitations of the ML offence together with the absence of a FT offense, the possibility of providing both MLA and extradition in relation to ML or FT appear rather limited. 


\section{Summary Table of Observance and Key Recommendations}

\begin{tabular}{|c|c|}
\hline FATF 40+9 Recommendations ${ }^{2}$ & Key Assessor Recommendations \\
\hline \multicolumn{2}{|c|}{ 1. Legal System and Related Institutional Measures } \\
\hline $\begin{array}{l}\text { Criminalization of Money } \\
\text { Laundering } \\
\text { R.1 - PC } \\
\text { R.2 - PC }\end{array}$ & $\begin{array}{l}\text { - Amend the legislation to include all the categories of serious offenses listed } \\
\text { by the FATF as predicate offenses of ML. } \\
\text { - Amend the CC to (1) include all the ML conducts in line with the Palermo } \\
\text { Convention; (2) allow proving that property is the proceeds of crime without } \\
\text { the need for a conviction of a predicate offence; (3) criminalize "conspiracy", } \\
\text { "facilitation" and "counseling" to commit ML; (4) re-categorize the offence } \\
\text { of ML as a crime (as opposed to a misdemeanor); and (5) raise the range of } \\
\text { sanctions to make them effective, proportional and dissuasive, relative to } \\
\text { other serious offences in the CC. }\end{array}$ \\
\hline $\begin{array}{l}\text { Criminalization of Terrorist } \\
\text { Financing } \\
\text { SR.II - NC }\end{array}$ & $\begin{array}{l}\text { - The offence of FT should be criminalized in keeping with the requirements of } \\
\text { the offence as set out in the SFT Convention. }\end{array}$ \\
\hline $\begin{array}{l}\text { Confiscation, freezing, and seizing } \\
\text { of proceeds of crime } \\
\text { R.3 - PC }\end{array}$ & $\begin{array}{l}\text { - Amend the CC to: (1) allow for the forfeiture of property of corresponding } \\
\text { value; and (2) allow for initial applications to seize property subject to } \\
\text { forfeiture to be made ex-parte or without prior notice. } \\
\text { - Allocate more resources to improving the conditions of the registries of } \\
\text { property. Speed up the informatization of the data bases, improve the facilities } \\
\text { where records are held, reduce the costs to registration, increase public } \\
\text { awareness on the benefits of registration, and amend appropriate laws to } \\
\text { sanction failures to register relevant acts and information. }\end{array}$ \\
\hline $\begin{array}{l}\text { Freezing of funds used for terrorist } \\
\text { financing } \\
\text { SR.III - NC }\end{array}$ & $\begin{array}{l}\text { - Put in place a system for freezing of terrorist assets ex parte and without } \\
\text { delay, including (1) a mechanism for reviewing and giving effect to, if } \\
\text { appropriate, the actions initiated under freezing mechanisms of other } \\
\text { countries; recognizing and reviewing terrorist lists of other countries and } \\
\text { giving effect to those lists if appropriate; and (2) Clear guidance on } \\
\text { implementation to financial institutions and other persons or entities that may } \\
\text { be holding targeted funds or other assets concerning their obligations in } \\
\text { taking action under freezing mechanisms. } \\
\text { Put in place procedures to examine and give effect to the actions initiated } \\
\text { under the freezing mechanisms of other jurisdictions. }\end{array}$ \\
\hline $\begin{array}{l}\text { The Financial Intelligence Unit and } \\
\text { its functions } \\
\text { R.26-PC }\end{array}$ & $\begin{array}{l}\text { - Strengthen financial analysis capacity of UAF staff and the processing of } \\
\text { STRs. } \\
\text { Provide the UAF has adequate resources and autonomy to allow its staff to } \\
\text { focus on their core mission; }\end{array}$ \\
\hline $\begin{array}{l}\text { Law enforcement, prosecution and } \\
\text { other competent authorities } \\
\text { R.27- NC } \\
\text { R.28 - C }\end{array}$ & $\begin{array}{l}\text { - Develop a training program of training focused on operative investigations } \\
\text { and the coordination of the law enforcement agencies. } \\
\text { Develop a program at the national level for specialized training for judges, } \\
\text { focusing on the interpretation of evidence in ML and FT cases, and on the }\end{array}$ \\
\hline
\end{tabular}

${ }^{2}$ Compliant (C): the Recommendation is fully observed with respect to all essential criteria. Largely compliant (LC): there are only minor shortcomings, with a large majority of the essential criteria being fully met. Partially compliant (PC): the country has taken some substantive action and complies with some of the essential criteria. Non-compliant (NC): there are major shortcomings, with a large majority of the essential criteria not being met. Not applicable (NA): a requirement or part of a requirement does not apply, due to the structural, legal or institutional features of a country. 


\begin{tabular}{|c|c|}
\hline & autonomy of these offences. \\
\hline $\begin{array}{l}\text { Cross Border Declaration or } \\
\text { disclosure } \\
\text { SR IX - NC }\end{array}$ & $\begin{array}{l}\text { - Take measures to apply an effective control on the cross-border cash } \\
\text { transport. SEPRELAD should coordinate with customs and police authorities } \\
\text { for an effective implementation of the measures of its Resolution No. } 61 \text {. }\end{array}$ \\
\hline \multicolumn{2}{|r|}{ 2. Preventive Measures: Financial Institutions } \\
\hline \multicolumn{2}{|l|}{$\begin{array}{l}\text { Risk of money laundering or } \\
\text { terrorist financing }\end{array}$} \\
\hline $\begin{array}{l}\text { Customer due diligence, including } \\
\text { enhanced or reduced measures } \\
\text { R.5 - NC } \\
\text { R.6- NC } \\
\text { R.7 - NC } \\
\text { R.8 - PC }\end{array}$ & $\begin{array}{l}\text { Establish, through law, a prohibition for financial institutions (FI) to opening } \\
\text { anonymous accounts or accounts in fictitious names; and an obligation to } \\
\text { identify and undertake customer due diligence (CDD) measures, including for } \\
\text { the beneficial owner when establishing the business relationship. } \\
\text { Establish through law, regulation, or other enforceable means (OEM) clear } \\
\text { requirements for FI to conduct adequate and enhanced CDD measures on legal } \\
\text { arrangements; relationships with money remitters; and higher risk categories of } \\
\text { customer, business relationships, or transactions. } \\
\text { Establish requirements for FI to: reject opening an account when unable to } \\
\text { complete CDD and to consider making a STR; consider terminating the } \\
\text { relationship and making a STR when the relationship has commenced and the FI } \\
\text { is unable to complete the CDD; and 6) maintain up-to-date customer records. } \\
\text { Establish requirements for insurance companies under the SIS to apply CDD } \\
\text { measures on existing customers on the basis of materiality and risk and to } \\
\text { conduct due diligence on such relationships at appropriate times. } \\
\text { Establish through law, regulation, or OEM clear requirements for FI to have } \\
\text { appropriate risk management systems to deal with PEPs in line with R.6. } \\
\text { Establish clear requirements for FI to deal with correspondent relationships. } \\
\text { Establish clear requirements for FI under the INCOOP to deal with non face-to- } \\
\text { face transactions and new technologies. }\end{array}$ \\
\hline $\begin{array}{l}\text { Third parties and introduced } \\
\text { business } \\
\text { R.9 - N/A }\end{array}$ & - $\quad$ Not applicable. \\
\hline $\begin{array}{l}\text { Financial institution secrecy or } \\
\text { confidentiality } \\
\text { R.4- PC }\end{array}$ & $\begin{array}{l}\text { Establish formal mechanisms and/or effective measures for competent } \\
\text { authorities to share information, without the need of a court order. }\end{array}$ \\
\hline $\begin{array}{l}\text { Record keeping and wire transfer } \\
\text { rules } \\
\text { R.10 - PC } \\
\text { SR.VII - NC }\end{array}$ & $\begin{array}{l}\text { Establish a legal obligation for recordkeeping for FI to maintain and retain all } \\
\text { customer records and business correspondence for at least five years after the } \\
\text { business relationship is ended, or longer period, if requested by the competent } \\
\text { authorities, and to make the data available to competent authorities. } \\
\text { Modify existing resolution for FI under the SIB in line with SR.VII and monitor } \\
\text { compliance. }\end{array}$ \\
\hline $\begin{array}{l}\text { Monitoring of transactions and } \\
\text { relationships } \\
\text { R.11 - NC } \\
\text { R.21 - NC }\end{array}$ & $\begin{array}{l}\text { - } \quad \text { Establish clear requirements for FI to comply with R.11. } \\
\text { - } \quad \text { Establish clear requirements for FI to comply with R.21. }\end{array}$ \\
\hline $\begin{array}{l}\text { Suspicious transaction reports and } \\
\text { other reporting } \\
\text { R.13- PC } \\
\text { R.14 - C } \\
\text { R.19 - NC } \\
\text { R.25 - NC } \\
\text { SR.IV - NC }\end{array}$ & $\begin{array}{l}\text { Define the term "financial institutions" and expand the list of FI in line with the } \\
\text { Assessment Methodology. } \\
\text { - } \\
\text { Modify the existing legal obligation to establish the requirement for financial } \\
\text { institutions to report directly to the SEPRELAD. } \\
\text { - Consider implementing a currency reporting requirement in line with R.19. } \\
\text { Establish a legal obligation for FI to report to the FIU transactions suspected or } \\
\text { linked to terrorism in line with SR. IV. } \\
\text { Provide guidance to FI to improve their AML/CFT procedures. }\end{array}$ \\
\hline
\end{tabular}




\begin{tabular}{|c|c|}
\hline & Establish communication standards and a feedback mechanism. \\
\hline $\begin{array}{l}\text { Internal controls, compliance, audit } \\
\text { and foreign branches } \\
\text { R. } 15-\text { PC } \\
\text { R. } 22-\mathrm{NC}\end{array}$ & $\begin{array}{l}\text { - Establish clear requirements for FI, including for money remitters, to develop } \\
\text { and maintain adequate programs against ML and FT, including internal controls, } \\
\text { screening procedures, compliance officers, independent audit, and training in } \\
\text { line with R.15. } \\
\text { Establish clear requirements for branches and subsidiaries of FI to pay particular } \\
\text { attention to transactions from some countries in line with R.22. }\end{array}$ \\
\hline $\begin{array}{l}\text { Shell banks } \\
\text { R.18 - LC }\end{array}$ & Clearly prohibit the establishment of shell banks in Paraguay. \\
\hline $\begin{array}{l}\text { Supervisory and oversight system- } \\
\text { competent authorities and SROs } \\
\text { Role, functions, duties and powers } \\
\text { (including sanctions) } \\
\text { R.17 - NC } \\
\text { R.23 - NC } \\
\text { R.29 - NC }\end{array}$ & $\begin{array}{l}\text { - Ensure that effective, proportionate and dissuasive administrative sanctions are } \\
\text { available to the competent supervisory authorities in line with R.17. } \\
\text { Designate a competent authority to regulate and supervise money remitters on } \\
\text { AML/CFT matters. } \\
\text { - Establish explicit and clear measures to prevent criminals or their associates } \\
\text { from owning or controlling a FI. } \\
\text { - Establish explicit fit and proper measures for directors and senior management } \\
\text { of FI. } \\
\text { Establish a direct obligation that empowers the SIB, the SIS, the CNV, and the } \\
\text { INCOOP to supervise and sanction FI on AML matters. } \\
\text { Strengthen the SIB, the SIS, the CNV, and the INCOOP overall supervisory } \\
\text { process to effectively address AML/CFT matters. }\end{array}$ \\
\hline $\begin{array}{l}\text { Money value transfer services } \\
\text { SR.VI - NC }\end{array}$ & $\begin{array}{l}\text { - Designate a supervisory body responsible for the licensing, regulation and } \\
\text { supervision of money or value transfer service (MVTS) operators. } \\
\text { - } \quad \text { Investigate and monitor informal MVTS systems. }\end{array}$ \\
\hline \multicolumn{2}{|c|}{ 3. Preventive Measures: Non-Financial Businesses and Professions } \\
\hline $\begin{array}{l}\text { Customer due diligence and record- } \\
\text { keeping } \\
\text { R.12-NC }\end{array}$ & $\begin{array}{l}\text { - All DNFBPs should be made subject to CDD and record-keeping requirements. } \\
\text { Ensure the application of CDD by DNFBPs with respect to politically exposed } \\
\text { persons, in the case of the use of new technologies, and in the case of reliance on } \\
\text { intermediaries or third parties. }\end{array}$ \\
\hline $\begin{array}{l}\text { Suspicious transaction reporting } \\
\text { R.16-NC }\end{array}$ & $\begin{array}{l}\text { - Lawyers and other independent legal professionals should be required to report } \\
\text { suspicions. } \\
\text { The recommendations made regarding R.13,14, 15, and } 21 \text { should also apply to } \\
\text { DNFBPs. }\end{array}$ \\
\hline $\begin{array}{l}\text { Regulation, supervision, } \\
\text { monitoring, and sanctions } \\
\text { R.24 - NC } \\
\text { R.25 - NC }\end{array}$ & $\begin{array}{l}\text { - Supervisory authorities should be specifically charged with the AML/CFT } \\
\text { regulation and supervision of all DNFBPs. } \\
\text { Establish guidelines to help DNFBPs implement and comply with AML/CFT } \\
\text { requirements. The FIU could be assigned the role of establishing such } \\
\text { guidelines. }\end{array}$ \\
\hline $\begin{array}{l}\text { Other non-financial businesses and } \\
\text { professions } \\
\text { R.20-NC }\end{array}$ & $\begin{array}{l}\text { Extend CDD requirements to pawnbrokers and identify other non-financial } \\
\text { businesses and professions that may be vulnerable and consider extending } \\
\text { AML/CFT requirements to them. } \\
\text { - Apply measures to provide greater incentive for developing modern and secure } \\
\text { transaction techniques. }\end{array}$ \\
\hline \multicolumn{2}{|c|}{ 4. Legal Persons and Arrangements \& Nonprofit Organizations } \\
\hline $\begin{array}{l}\text { Legal Persons-Access to beneficial } \\
\text { ownership and control information } \\
\text { R.33-NC }\end{array}$ & $\begin{array}{l}\text { - Introduce mechanisms to provide transparency regarding the beneficial owners } \\
\text { and controllers of legal persons. } \\
\text { Adopt measures to allow competent authorities to obtain or have access in a } \\
\text { timely fashion to adequate, accurate, and current information on beneficial } \\
\text { ownership and control of legal persons. }\end{array}$ \\
\hline
\end{tabular}




\begin{tabular}{|c|c|}
\hline $\begin{array}{l}\text { Legal Arrangements-Access to } \\
\text { beneficial ownership and control } \\
\text { information } \\
\text { R.34-NC }\end{array}$ & $\begin{array}{l}\text { - Adopt measures to prevent the unlawful use of trusts in relation to money } \\
\text { laundering by ensuring that commercial, trust and other laws require adequate } \\
\text { transparency concerning the ownership and control of trusts. } \\
\text { Adopt measures that may allow competent authorities to obtain or have access in } \\
\text { a timely fashion to adequate, accurate, and current information on beneficial } \\
\text { ownership and control of legal persons. }\end{array}$ \\
\hline $\begin{array}{l}\text { Nonprofit organizations } \\
\text { SR.VIII - NC }\end{array}$ & $\begin{array}{l}\text { Implement adequate measures in line with the FATF requirement. In particular: } \\
\text { (1) carry out a comprehensive domestic review of the non-profit sector; (2) } \\
\text { adopt the necessary measures to protect this sector from terrorist financing } \\
\text { through outreach and effective oversight; and (3) implement effective domestic } \\
\text { co-operation and information-sharing mechanisms among competent authorities } \\
\text { that hold information on non-profit organizations. }\end{array}$ \\
\hline \multicolumn{2}{|r|}{ 5. National and International Cooperation } \\
\hline $\begin{array}{l}\text { National cooperation and } \\
\text { coordination } \\
\text { R.31 - NC }\end{array}$ & $\begin{array}{l}\text { Establish formal and informal mechanisms to support cooperation and } \\
\text { coordination at policy-making and operational levels among the various law } \\
\text { enforcement authorities, the UAF, and other competent authorities involved in } \\
\text { combating ML/FT. } \\
\text { Establish mechanisms to facilitate consultation between competent authorities, } \\
\text { the financial sector and other sectors (including all DNFBPs) on implementation } \\
\text { of the AML/CFT laws, regulations, guidelines or other measures. }\end{array}$ \\
\hline $\begin{array}{l}\text { The Conventions and UN Special } \\
\text { Resolutions } \\
\text { R.35 - PC } \\
\text { SR.I - NC }\end{array}$ & $\begin{array}{l}\text { - Amend the AML Law and enact CFT legislation to fully cover the ML and TF } \\
\text { offences and thus completely implement the Vienna, Palermo and Terrorist } \\
\text { Financing Conventions. } \\
\text { Implement the UNSC Resolutions by developing and executing the necessary } \\
\text { procedures and mechanisms. }\end{array}$ \\
\hline $\begin{array}{l}\text { Mutual Legal Assistance } \\
\text { R.36- PC } \\
\text { R.37- LC } \\
\text { R.38 - NC } \\
\text { SR.V - NC }\end{array}$ & $\begin{array}{l}\text { - Establish specific provision for applying provisional measures at the request of a } \\
\text { foreign country for search, seizure and confiscation. } \\
\text { Consider establishing an asset forfeiture fund, as well as arrangements for } \\
\text { coordinating seizure or confiscation actions with other countries and to share } \\
\text { confiscated assets with other countries which participated in coordinated action. }\end{array}$ \\
\hline $\begin{array}{l}\text { Extradition } \\
\text { R.39- PC } \\
\text { R.37 - LC } \\
\text { SR.V - NC }\end{array}$ & $\begin{array}{l}\text { - Consider enhancing procedures to ensure that extradition requests are not unduly } \\
\text { delayed and provide for alternative simplified procedures for extradition on a } \\
\text { case-by-case basis. } \\
\text { Establish statistical tools in order to have the ability to provide an accurate } \\
\text { accounting of extradition requests received and sent }\end{array}$ \\
\hline $\begin{array}{l}\text { Other Forms of Cooperation } \\
\text { R. } 40 \text { - PC } \\
\text { SR.V - NC }\end{array}$ & $\begin{array}{l}\text { - Consider establishing operational task forces at an early stage of investigations } \\
\text { at regional level of criminal matters involving the proceeds of crime, money } \\
\text { laundering and terrorist financing. }\end{array}$ \\
\hline \multicolumn{2}{|r|}{ 6. Other Issues } \\
\hline $\begin{array}{l}\text { Resources \& Statistics } \\
\text { R.30 - NC } \\
\text { R.32 - NC }\end{array}$ & $\begin{array}{l}\text { - Conduct a review of the effectiveness of the cooperation and coordination } \\
\text { systems for AML/CFT in the short term and thereafter on a regular basis. } \\
\text { Statistics should be updated and maintained in line with the recommendations in } \\
\text { Rec. } 32 \text {. }\end{array}$ \\
\hline $\begin{array}{l}\text { Other relevant } \mathrm{AML} / \mathrm{CFT} \\
\text { measures or issues }\end{array}$ & $\bullet$ \\
\hline $\begin{array}{l}\text { General framework - structural } \\
\text { issues }\end{array}$ & $\bullet$ \\
\hline
\end{tabular}




\section{H. Authorities' Response}

28. The government of Paraguay, under the leadership of His Excellency, President Fernando Lugo Méndez, considers it a priority to be at the forefront of preventing money laundering and terrorist financing in our region. The government of Paraguay concurs with the assessors on most of the strengths and weaknesses pointed out in the detailed assessment report. Beyond any lingering differences of opinion regarding the report, the understanding is that the focus ought now to be on the points of convergence inasmuch as they are essential to fleshing out the diagnostic assessment of the situation and the design of the AML/CFT National Action Plan.

29. The government of Paraguay, which took office on August 15, 2008, has publicly stated its firm commitment to take all the required measures to reduce the country's vulnerabilities to organized crime and especially as it relates to money laundering and the financing of terrorism. As such, the assessment of Paraguay's AML/CFT regime was considered a matter of State to be addressed through interinstitutional efforts involving the management and staff of all the relevant institutions.

30. The report analyzed here focuses in particular on such risks and the measures taken to counter them, in accordance with the FATF Recommendations, but it pursues a strictly static approach, without incorporating key data derived from the current situation. In particular it repeats the portrayal of a country geared toward agricultural and livestock rearing activities for the most part. This view should at least be tempered by the fact that a political sea change has taken place in Paraguay, which will undoubtedly lead to a major proactive role in the years to come, unlike previous administrations.

31. We have achieved continuous and consistent achievements, although we still have a long way to go. Nevertheless, we appreciate the fact that we are not alone in this effort. The support that we receive from neighboring countries, international organizations, and cooperating nations provides important incentives for us to continue our fight against these crimes.

32. We faced certain difficulties due to the fact that the initial draft assessment report received was in English and we had to translate it before distributing it to the relevant institutions for their review and comments. We experienced similar difficulties with the second draft, however, this time and given the urgency for submitting comments, the institutions worked with the English version. As a demonstration of our commitment and the importance we assign to this matter, and in spite of the difficulties and shortness of time, we provided our comments and observations to the group of assessors in a timely manner.

33. It is important to mention that since the assessment visit, several actions have been taken with the objective of implementing the recommendations provided in the assessment report, even before the report is approved by GAFISUD. Among the corrective actions taken, we would like to highlight the following:

\section{$\checkmark$ Submission of the draft amendment of Law 1015/97 "Preventing and punishing illicit acts intended to legitimize money or assets".}

The draft has three key aspects: 
34. With respect to the applicability of the law, its scope is broadened as provided in Law 2381/04, which ratifies the Convention against Terrorism. It seeks to legitimize the powers of SEPRELAD (Money and Asset Laundering Prevention Secretariat) to demand that the parties required to report file Suspicious Activities Reports (SARs) on operations related to the financing of terrorism.

35. It establishes SEPRELAD as a Secretariat with the status of a Ministry, reporting exclusively to the Office of the President of the Republic. The Secretariat is currently set up as a collegiate body of six officials from different government institutions.

36. It includes and expands sectoral coverage of the law to include nonfinancial activities and professions, and sectors engaged in general commercial activities, which involve transfers of money or assets, whether formal or informal, in accordance with the Law.

37. A draft presidential decree is in preparation, which advocates that a structural organization chart for SEPRELAD be established for the duration of Law 1015/97 on money laundering. The Law has a major omission: it makes no mention of a general directorate, subdirectorates, or their functions.

38. Our achievements to date include:

Support for the legislative initiative of the Committee against Drug Trafficking and Related Serious Crimes of the House of Deputies, with respect to the submission of planned amendments to Law 1015/97.

$\checkmark$ Extension of the Egmont suspension to March 2009. In that regard, we have had discussions with the President of Paraguay, who indicated that he would promote bills related to combating the scourge of money laundering and the financing of terrorism.

Technical cooperation from the government of Brazil to reform Paraguayan legislation on the financing of terrorism.

$\checkmark$ Submission of a draft advocating the approval of a structural organization chart of the Secretariat, pending the amendment of Law 1015/97.

39. The draft was given the nod by the Legal Section of the Office of the President of the Republic, which is the last step before the forthcoming issue of the Presidential Decree.

$\checkmark$ Technological advances: work has been started on IT initiatives that enhance the feasibility of the project to connect reporting parties so that they can receive SARs electronically.

$\checkmark$ Broadening of the budget.

$\checkmark$ Amendment of resolutions: an initial draft amendment of Resolution $\mathrm{N}^{\mathrm{o}} 263$ on the insurance sector has been completed and work is being done on other resolutions.

$\checkmark$ Interinstitutional agreements on information sharing between:

- Central Bank of Paraguay - Superintendency of Insurance

- Ministry of Finance - Undersecretariat of State for Taxation 
- National Anti-drug Secretariat (SENAD).

$\checkmark$ Drafting of the tentative 2009 program of training delivered and received by SEPRELAD, in the course of its duties.

40. Based on the aforementioned observations, we agree with the assessors' conclusions and we think that the assessment report fairly reflects the actual situation of our AML/CFT regime.

February 20, 2009 